\title{
PRAWO A SPRAWIEDLIWOŚĆ W PROCESIE SĄDOWEJ INTERPRETACJI NORM PRAWA DO ŚWIADCZEŃ RODZINNYCH
}

\begin{abstract}
Abstrakt: Artykuł ma na celu zwrócenie uwagi na problem „omijania” przez sądy administracyjne literalnej treści przepisów prawa i koncentrowania się na idei sprawiedliwości i równości. Problem ten jest szczególnie widoczny w odniesieniu do problematyki świadczeń społecznych. Prowadzić może do zaburzenia poczucia jednolitości i jasności prawa wśród obywateli.
\end{abstract}

Słowa kluczowe: świadczenia rodzinne, wykładnia prawa, sądownictwo administracyjne, sprawiedliwość, administracja publiczna

\section{WPROWADZENIE}

Niezależność orzecznicza składów sędziowskich sądów administracyjnych, a także — bez wątpienia słuszny — brak w obowiązującym prawie zasady ujednolicania rozstrzygnięć sądowoadministracyjnych przyczynia się do tego, że część sędziów przedkłada stosowanie się do idei „sprawiedliwości” czy „równości” ponad ścisłe podporządkowanie się treści przepisów prawa i woli prawodawcy.

Szczególnie widoczne staje się to w odniesieniu do problematyki świadczeń rodzinnych (prowadzących do zaspokajania potrzeb jednostek i rodzin oraz ich bezpieczeństwa socjalnego). Wydawane są wyroki, których uzasadnienie pokazuje, że dany sąd, prowadząc wykładnię prawa, uznaje jego obowiązujące przepisy za niesprawiedliwe, niezgodne z podstawowymi zasadami konstytucyjnymi, po czym dokonuje takiej ich interpretacji, która bywa zupełnie niezgodna $\mathrm{z}$ literalnym brzmieniem przepisu, a tym bardziej z polityczną wolą (celem) ustawodawcy wprowadzającego przepisy w życie.

Warto zatem - bez podejmowania prób oceny zasadności wyroków sądowych - zwrócić uwagę na przykłady takiego orzecznictwa, zwłaszcza że może prowadzić do zaburzenia poczucia jednolitości i jasności prawa wśród obywateli. Aby jednak podjąć problem rozbieżności orzeczniczej opartej na „sprawiedliwo- 
ści”, niezbędne jest wskazanie jak tę „sprawiedliwość” można rozumieć, a także, na początek, sygnalizacyjnie przypomnieć o rodzajach wykładni prawa ze względu na metodę ich prowadzenia (takie bowiem rodzaje wykładni uznaję za najczęściej występujące w praktyce).

\section{ZASADY INTERPRETACJI PRAWA STOSOWANE W ORZECZNICTWIE SĄDOWYM}

Wykładnia prawa - jak pisze Marek Zirk-Sadowski - ma na celu określenie, jakie stany faktyczne spełniają normę, to jest odnosi się do określonego stanu rzeczywistości i daje odpowiedź na pytanie, czy określony stan faktyczny spełnia daną normę. Autor ten zauważa, że wykładnia przebiega w dwóch etapach, to jest ustalenia znaczenia normy za pomocą dyrektyw dobranych do rodzaju wątpliwości interpretacyjnej, a następnie dokonania wyboru spośród uzyskanych wyników interpretacyjnych ${ }^{1}$.

Wojciech Jakimowicz precyzuje, że celem wykładni jest „odkodowanie tak zwanych norm prawa administracyjnego, które stanowią podstawę działania organu administracji $\mathrm{w}$ toku postępowania administracyjnego (jurysdykcyjnego) oraz zagwarantowanie poprawnego wykreowania norm prawa administracyjnego o charakterze indywidualnym i konkretnym"2.

Jednocześnie aktualne orzecznictwo sądów administracyjnych prowadzi do wniosku, że wątpliwości interpretacyjne rozstrzygane są najczęściej za pomocą wykładni: językowej, celowościowej, systemowej, funkcjonalnej, logicznej, historycznej, porównawczej, jak też prowspólnotowej.

Analiza języka przepisu, a zatem wykładnia językowa, to - jak poucza Najwyższy Sad Administracyjny — ,proces ustalania treści norm prawnych na podstawie możliwego sensu słów, za pomocą których sformułowano dany przepis"3. Sąd ten wskazuje, że wykładnia tego rodzaju „dąży do wyjaśnienia sensu przepisu prawnego przez analizę tekstu słownego przepisu, w szczególności przez ustalenie

1 A. Zirk-Sadowski, Pojęcie, koncepcje i przebieg wykładni prawa administracyjnego, [w:] System prawa administracyjnego, red. R. Hauser, Z. Niewiadomski, A. Wróbel, t. 4, Warszawa 2015; zob. też Wykładnia w prawie administracyjnym, red. L. Leszczyński, B. Wojciechowski, M. Zirk-Sadowski, Warszawa 2012, s. 163-164.

2 W. Jakimowicz, Wyktadnia w prawie administracyjnym, Kraków 2006, https://sip.lex. $\mathrm{pl} / \# /$ monograph/369152585/23/jakimowicz-wojciech-wykladnia-w-prawie-administracyjnym? keyword=\%22poj\%C4\%99cie $\% 20$ sprawiedliwo $\%$ C5\%9Bci\%22\&unitId=passage_1561 (dostęp: 2.10.2020).

3 Uchwała NSA z dnia 4 czerwca 2001 roku, FPK 5/01, ONSA z 2001 r. nr 4, poz. 160; podobnie w uchwale NSA z dnia 22 kwietnia 2002 roku, FPS 2/02, ONSA z 2002 r. nr 4, poz. 136 oraz w wyroku WSA w Warszawie z dnia13 października 2004 roku, III SA 2419/03, Centralna Baza Orzeczeń Sądów Administracyjnych 2005, nr 1, s. 32. 
znaczenia użytych w nim zwrotów (analiza semantyczna) przy uwzględnieniu obowiązujących reguł gramatycznych"4.

Wykładnia systemowa dokonywana ze szczególnym uwzględnieniem systemu prawa, w którym funkcjonuje dany przepis, obejmuje — jak pisze Bogumił Brzeziński — „wszystkie dyrektywy interpretacyjne, które nie mieszczą się w wykładni językowej oraz wykładni celowościowej”, a także ,gromadzi i wykorzystuje argumentację związaną ze strukturą (organizacją) sytemu prawa oraz wartościami, które leżą u jego podłoża"s. Sądy zaś precyzują, że systemowość wymaga zbadania, „czy na podstawie innych przepisów tego samego aktu normatywnego można określić znaczenie danego pojęcia"6.

Wykładnia celowościowa nakazuje interpretować normę z uwzględnieniem celu, jaki ma realizować przepis. Jak pisał Eugeniusz Smoktunowicz, prawo jako narzędzie celowego organizowania stosunków społecznych składa się (oprócz formy) także z treści, którą nazywa „duszą prawa”, toteż

ustalanie jego znaczenia nie może się ograniczyć do badania tylko formy, lecz musi uwzględniać także, a może nawet przede wszystkim, jego sens, tzn. cel lub cele, które dana regulacja prawna ma realizować. [...] Pomijanie celu regulacji prawnej i ustalanie jej znaczenia wyłącznie przy pomocy analizy słów jest głównym i najczęściej występującym błędem w rozumieniu i stosowaniu prawa administracyjnego ${ }^{7}$.

Podobnie twierdzą sądy administracyjne. W opinii NSA wykładnia celowościowa polega na

zrozumieniu celu, w jakim dany przepis został powołany [...], ponieważ cel powołania przepisu jest jedynym i pierwotnym powodem, dla którego został on ujęty w językowe ramy i utrwalony w normie prawnej. Stąd też z chwilą pojawienia się jakiejkolwiek wątpliwości, w tym znaczeniu, że powołany przepis może mieć inne niż językowe znaczenie, Sąd powinien podjąć próbę rozstrzygnięcia znaczenia poddanego wykładni przepisu prawnego z zastosowaniem pozostałych metod wykładni ${ }^{8}$.

Z kolei wykładnia funkcjonalna, dokonywana na podstawie funkcji przepisu, odwołuje się — jak pisze Grzegorz Jędrejek — do wartości, które chroni ustawodawca. Jego zdaniem ,rezultatem wykładni funkcjonalnej jest uzyskanie takiego sensu przepisów, który ma najsilniejsze uzasadnienie aksjologiczne"9.

4 Wyrok NSA z dnia 12 czerwca 2002 roku, III SA 314/02, LEX nr 263433.

5 B. Brzeziński, Podstawy wyktadni prawa podatkowego, Gdańsk 2008, s. 95-96.

${ }^{6}$ Wyrok WSA w Warszawie z dnia 8 listopada 2010 roku, III SA/Wa 748/10, LEX nr 736498.

7 E. Smoktunowicz, Orzecznictwo Sądu Najwyższego i Naczelnego Sądu Administracyjnego: kodeks postępowania administracyjnego, Warszawa 1994, s. 32.

8 Wyrok NSA, z dnia 19 czerwca 2019 roku, I GSK 1692/18.

9 G. Jędrejek, Wykładnia przepisów prawa cywilnego materialnego i procesowego, Warszawa 2020, https://sip.lex.pl/\#/monograph/369461896/25/jedrejek-grzegorz-wykladnia-przepisow-prawa-cywilnego-materialnego-i-procesowego?keyword $=\% 22 \mathrm{wyk} \% \mathrm{C} 5 \% 82 \mathrm{adnia} \% 20$ funkcjonalna\%22\&cm=SREST (dostęp: 28.09.2020). 
Wykładnia tego rodzaju polega na ustalaniu znaczenia przepisu w oparciu o warunki, które - jak wskazuje NSA — „decydują o funkcji i treści danego przepisu”, przy czym w jej ramach ,uwzględnia się przede wszystkim cel danej regulacji prawnej, to jest skutki, jakie zgodnie z zamierzeniem ustawodawcy ma ona osiągnąć"10.

Zasady logiki pozwalają na interpretację prawa za pomocą wykładni logicznej. We wcześniejszej doktrynie prawniczej (obecnie niezbyt często operuje się tym rodzajem dyrektyw interpretacyjnych) przyjmowano, że logika pozwala na wyjaśnianie treści normy prawnej „w ścisłym znaczeniu tego słowa”. Aktualnie zaś ,,to określenie odpowiada w pewnym przybliżeniu dzisiaj używanemu pojęciu wnioskowań prawniczych"11.

Możemy mówić również o wykładni dokonywanej na podstawie kontekstu dziejowego. Jest to tak zwana wykładnia historyczna. Polega ona na interpretowaniu obowiązującego prawa z uwzględnieniem wcześniejszych regulacji prawnych oraz okoliczności, w których zostały one wdrożone i obowiązywały.

Jędrejek pisze, że ,metoda historyczna, jak sama nazwa wskazuje, sięga nie tylko do badania prac legislacyjnych nad obowiązującymi przepisami, ale do regulacji, które obowiązywały wcześniej. Niestety, jest ona dość rzadko stosowana ze względu na czasochłonność, a także na konieczność przeanalizowania wielu materiałów badawczych"12.

Podobnie istotę tej wykładni widzi Eugeniusz Waśkowski, który wskazywał, że polega ona na poszukiwaniu ,,argumentów przemawiających za określonym znaczeniem tekstu prawa na podstawie zmian regulacji prawnej i różnicy pomiędzy pierwotną a późniejszą wersją tegoż tekstu"13.

Nie sposób nie wspomnieć także o wykładni porównawczej, zwanej komparatystyczną, której istota sprowadza się do porównywania podobnych przepisów z innych systemów prawnych. Wykładnia ta polega na ustalaniu znaczenia norm prawnych, które zostały zawarte w interpretowanych przepisach, poprzez porównanie ich z identycznymi bądź podobnymi regulacjami prawnymi.

Interpretacja prawa może być również prowadzona w oparciu o treść prawa Unii Europejskiej (wykładnia prowspólnotowa). Jak twierdzi Zbigniew Radwański, pomocniczą rolę w interpretacji prawa UE ,odgrywa wykładnia porównawcza zalecająca uwzględnienie regulacji prawnych zawartych w prawach krajowych"14.

10 Wyrok NSA z dnia 17 kwietnia 2019 roku, II OSK 1495/17.

11 E. Waśkowski, Teorja wykladni prawa cywilnego. Metodologja dogmatyki cywilistycznej $w$ zarysie, Warszawa 1936, s. 17-20.

12 G. Jędrejek, op. cit.

13 T. Grzybowski, Wptyw zmian prawa na jego wykładnię, Warszawa 2013.

14 Z. Radwański, Zastosowanie wykładni językowej w prawie Unii Europejskiej, [w:] Aurea praxis. Aurea theoria. Księga pamiątkowa ku czci Profesora Tadeusza Erecińskiego, t. 2, red. J. Gudowski, K. Weitz, Warszawa 2011, https://sip.lex.pl/\#/monograph/369382833/152/gudowskijacek-red-weitz-karol-red-aurea-praxis-aurea-theoria-ksiega-pamiatkowa-ku-czci-profesora...? 
Co jednak kluczowe, wykładnia tego rodzaju zakłada, że w okoliczności, gdy konieczne jest orzekanie w oparciu o przepisy z krajowego i unijnego porządku prawnego, a nie da się ich — z powodu sprzeczności i wzajemnej niezgodności spójnie zastosować, organ stosujący prawo powinien oprzeć się na normach prawa wspólnotowego i na ich podstawie podjąć rozstrzygnięcie w sprawie.

Jak zauważa Wojciech Jakimowicz, ,w orzecznictwie ETS wskazuje się wyraźnie - w kontekście pierwszeństwa prawa wspólnotowego - na obowiązek wykładni prawa krajowego zgodnie z prawem wspólnotowym". Autor ten powołując się na ETS, wskazuje, że „granicą” obowiązku dokonywania prowspólnotowej wykładni prawa przez sądy krajowe są ogólne zasady prawa stanowiące część prawa wspólnotowego, a przede wszystkim zasady pewności prawa i zakazu działania prawa wstecz ${ }^{15}$.

Z kolei z orzecznictwa polskich sądów administracyjnych wyłania się konstatacja zupełnie odmienna. Sądy te pouczają, że wykładnia prounijna nie powinna mieć miejsca, gdy będzie prowadziła do rezultatów sprzecznych z efektami wykładni językowej. Mogłoby to bowiem, szczególnie w odniesieniu do stosowania w przestrzeni prawnej dyrektyw UE - jak czytamy w uzasadnieniu do wyroku wydanego przez WSA w Poznaniu - ,doprowadzić do niedopuszczalnej wykładni contra legem”, albowiem „prawo do bezpośredniego stosowania dyrektywy z pominięciem przepisów krajowych nie może być wykorzystywane przez organy państwa w celu ograniczenia praw wynikających z przepisów krajowych"16.

Co jednak zasadnicze, w orzecznictwie sądowym widoczny jest prymat jednej z wyżej opisanych zasad interpretacyjnych, to jest wykładni językowej (literalnej, gramatycznej). Sądy administracyjne najczęściej stoją na stanowisku, że (jak na przyklad wskazuje NSA)

jedną z podstawowych zasad odczytywania znaczenia przepisów prawnych jest danie pierwszeństwa wykładni literalnej. Poszukiwania intencji prawodawcy tworzącego daną normę, przy użyciu wykładni celowościowej czy funkcjonalnej, jest zaś dopuszczalne i konieczne w sytuacji, gdy sformułowanie badanego przepisu nie jest czytelne, nie jest jednoznaczne, dopuszcza różne sposoby jego rozumienia lub też, jeżeli literalne rozumienie przepisu pozostawałoby w sprzeczności $\mathrm{z}$ celami, jakie ma realizować dany akt prawny ${ }^{17}$.

Sąd ten precyzował, że wykładnia „winna uwzględniać reguły znaczeniowe języka powszechnego, języka prawnego i języka prawniczego", zaś przy stosowaniu wykładni językowej jako dominującej metody interpretacji przepisów prawa pierwszeństwo winno się przyznać definicjom legalnym tekstu prawnego, albowiem „nie ma innych silniejszych reguł służących ustalaniu znaczenia zwrotów

keyword=\%22wyk\%C5\%82adni\%20por\%C3\%B3wnawczej\%22\&unitId=passage_7291 (dostęp: 5.01.2020).

15 Zob. W. Jakimowicz, Wyktadnia w prawie administracyjnym, Kraków 2006.

16 Wyrok WSA w Poznaniu z dnia 6 lutego 2020 roku, I SA/Po 920/19.

17 Wyrok NSA z dnia 3 lutego 2016 roku, I OSK 2564/15, LEX nr 2036044. 
użytych w przepisach prawnych”. NSA przyjął, że w „dalszej kolejności, gdy brak definicji legalnych, należy stosować reguły znaczeniowe języka prawniczego, orzecznictwa i doktryny". Natomiast dopiero gdy brakuje definicji legalnych i nie istnieje możliwość odwołania się do reguł języka prawniczego, ,przychodzi kolej na sięgnięcie do reguł znaczeniowych języka powszechnego zawartego z słownikach języka polskiego"18.

Powyższa koncepcja przyjmowana jest również w orzecznictwie Trybunału Konstytucyjnego. Przykładowo w wyroku K 25/99 TK podkreślił, że w państwie prawnym interpretator musi zawsze brać pod uwagę zwłaszcza językowe znaczenie tekstu prawnego ${ }^{19}$.

Podobne konkluzje można wywieść z wyroków Sądu najwyższego, w których wskazuje się, że wykładnia językowa, rozumiana jako gramatyczno-słownikowa, jest pierwszym, a co za tym idzie najważniejszym etapem analizy tekstu aktu prawa $^{20}$.

Nie inaczej twierdzi doktryna. Zdaniem Macieja Zielińskiego w polskiej kulturze prawnej przyjmuje się kolejność dyrektyw wykładni w takim układzie, że przede wszystkim stosuje się dyrektywy językowe, a później systemowe i końcowo funkcjonalne. Co przy tym ważne, w opinii tego autora odstępstwo od tej kolejności jest błędne ${ }^{21}$.

Za pierwszeństwem wykładni językowej oraz pomocniczości (subsydiarności) wykładni systemowej i funkcjonalnej opowiada się L. Morawski. Pisze on, że pomimo istnienia sporów doktrynalnych, praktyka prawnicza w sposób jednoznaczny opowiedziała się za priorytetem dyrektywy językowej ${ }^{22}$.

M. Cieślak zaś dodaje, iż wykładnia językowa jest oczywistą konsekwencją niemożności ignorowania przez ustawodawcę zwyczajowego, powszechnie przyjętego znaczenia użytych w aktach normatywnych wyrazów, a zasadą jest komunikowanie treści norm prawa za pomocą języka lokalnego, zrozumiałego dla odbiorcy, który poprzez analizę słów powinien odczytać właściwe znaczenie przekazu wynikającego z prawa ${ }^{23}$.

Nie sposób przy tym nie zauważyć, że występują również postulaty (a co za tym idzie i przytaczane przyczyny) odstąpienia od wykładni językowej. Sądy administracyjne wskazują bowiem, że niekiedy „dopuszczalne, a nawet konieczne jest odstąpienie od wykładni językowej, jeżeli za takim rozwiązaniem przema-

18 Wyrok NSA z dnia 14 grudnia 2000 roku, FSA 2/00, ONSA 2001/2, poz. 49.

19 Wyrok TK z dnia 28 czerwca 2000 roku, K 25/99, OTK 2000/5, poz. 141.

20 Uchwała SN z dnia 27 marca 1996 roku, III CZP 24/96, POP 1997/1, poz. 2.

21 M. Zieliński, Wybrane zagadnienia wykładni prawa, „Państwo i Prawo” 2009, z. 6, s. 8.

22 L. Morawski, Zasady wykładni prawa, Torun 2010, s. 73.

23 M. Cieślak, Polska procedura karna. Podstawowe założenia teoretyczne, Warszawa 1984, s. 172-173. Autor ten trafnie zauważa, że wszystkie inne metody wykładni są właściwie tylko sposobami weryfikacji rezultatów wykładni słownej, jeżeli budzą one wątpliwości. 
wiają nader istotne argumenty” 24 albo też, gdy „wykładnia językowa przepisu prowadziłaby do wniosków absurdalnych"25.

Przykładowo, WSA w Warszawie stwierdził, iż „skoro wykładnia prawa musi opierać się na założeniu racjonalności ustawodawcy, wewnętrznej spójności aktu prawnego, ale i całego sytemu prawa, to pominięcie wykładni językowej w niektórych przypadkach usprawiedliwia również konieczność nadania interpretowanym przepisom znaczenia, które uczyni je rozwiązaniami najtrafniejszymi prakseologicznie" 26 .

Podobną argumentację stosuje się w piśmiennictwie. P. Rogoziński co prawda wskazuje, iż „odrzucenie rezultatu wykładni językowej nie może nastąpić tylko $z$ tego powodu, że interpretator uznaje, iż bardziej celowe i sensowne byłoby inne rozwiązanie danej kwestii”, jednakże (zasadnie zresztą) twierdzi, że w okoliczności, ,gdy zostanie wykazane, iż sens językowy przepisu prowadzi do absurdu, jest ewidentnie sprzeczny z wartościami konstytucyjnymi lub innymi powszechnie akceptowanymi wartościami, dając efekt rażąco niesłuszny, niesprawiedliwy, nieracjonalny lub niweczący ratio legis przepisu, albo w sytuacji oczywistego błędu legislacyjnego" stosowanie wykładni językowej byłoby nieuzasadnione. ${ }^{27}$

Niektórzy autorzy (jak na przykład M. Zirk-Sadowski) pouczają wręcz, że ograniczenie się przez sądy wyłącznie do wykładni literalnej jest nieprawidłowe, albowiem konieczne jest ,potwierdzenie jej przez wykładnię systemową i funkcjonalną" ${ }^{28}$, przy czym — jak pisze A. Bielska-Brodziak — koncepcja „oczywistości” językowego znaczenia jest „oczywiście błędna”, z powodu wielości rejestrów językowych, pozostałych dyrektyw (argumentów) wymienianych w ramach wykładni językowej oraz faktu, że „wszystkie te narzędzia mogą prowadzić do wyboru całkowicie różnych hipotez znaczeniowych"29.

\section{POJĘCIE SPRAWIEDLIWOŚCI}

Sprawiedliwość, zgodnie z encyklopedią PWN, to „W refleksji etycznej kardynalna cnota porządkująca wybory ludzkiej woli lub normatywny punkt odniesienia dla rozumu wskazującego woli prawidłowy wybór; w refleksji prawniczej

24 Wyrok NSA z dnia 10 listopada 2011 roku, I FSK 1634/10.

25 Wyrok NSA z dnia 21 maja 2014 roku, I OSK 585/13.

26 Wyrok WSA w Warszawie z dnia 17 maja 2011 roku, III SA/Wa 2759/10.

27 P. Rogoziński, Glosa do uchwaty Sądu Najwyższego z dnia 29 października 2012 r., sygn. I KZP 15/12, „Prokuratura i Prawo” 2014, nr 1, s. 170-171.

28 M. Zirk-Sadowski, op. cit., s. 126-208.

29 A. Bielska-Brodziak, Interpretacja tekstu prawnego na podstawie orzecznictwa podatkowego, Warszawa 2009, https://sip.lex.pl/\#/monograph/369198482/35/bielska-brodziakagnieszka-interpretacja-tekstu-prawnego-na-podstawie-orzecznictwa-podatkowego?keyword= pierwsze $\%$ C5 $\% 84$ stwo $\% 20$ wyk $\%$ C5\%82adni $\% 20 j \% C 4 \% 99$ zykowej\&unitId=passage_541 (dostęp: 2.01.2021). 
kryterium dla norm prawnych, a nawet nie zawsze określany zbiór uprawnień przysługujących jednostkom lub/i grupom; w refleksji społecznej treść właściwego (pożądanego) ładu wspólnotowego, ewentualnie uwzględniająca potrzeby lub preferencje jednostki lub/i grupy" 30 .

W powszechnym rozumieniu idea sprawiedliwości zakłada równość oznaczającą, że wszyscy są do pewnego stopnia tacy sami (i jest możliwa w takim systemie prawnym, który znosi różnice między ludźmi, zrównując wszystkich jako obywateli mających te same uprawnienia), a sprawiedliwe są takie zasady życia społecznego, na które zgadzają się wolne i racjonalnie działające podmioty.

Jak piszą H. Walczak i P. Witkowski, z wyrażeniem ,sprawiedliwość” kojarzy się przede wszystkim porządek prawny, w którym „sędzia czyni zadość sprawiedliwości, sprawiając tym samym, że zostaje przywrócony szacunek dla prawa", przy czym „obowiązek przestrzegania sprawiedliwości sprowadza się ostatecznie do tego, by przy wszystkich zmianach i podziałach była zachowana równość"31.

A. Łazarska przypomina, że „o sprawiedliwość toczą się wojny, z jej powodu wybuchają rewolucje, skazuje się ludzi, pozbawia się jakichś dóbr jednych i przyznaje je innym, nadaje się i odbiera przywileje" 32 .

W. Jakimowicz, powołując się na Z. Kmieciaka, dodaje, iż: „sprawiedliwość proceduralna oznacza taką organizację procesu uzyskiwania informacji, ich analizy, wymiany argumentacji i podejmowania rozstrzygnięcia, która pozwala uznać wynik zastosowania procedury za sprawiedliwy (uczciwy, słuszny)"33.

Z kolei S. Nitecki, oceniając twierdzenia K. Głąbickiej, pisze, że sprawiedliwość jako zasada życia społecznego ma znaczenie porządkujące. Jego zdaniem sprowadza się do „zabezpieczenia każdej osobie takich dóbr i praw, które będą prowadziły do godnego życia człowieka", zaś jej istotą jest poszanowanie uprawnień człowieka, równe traktowanie wszystkich ludzi w zakresie przysługujących im dóbr i wartości i służenie dobru wspólnemu i indywidualnemu ${ }^{34}$.

30 Sprawiedliwość, [hasło w:] Encyklopedia PWN, https://encyklopedia.pwn.pl/haslo/sprawiedliwosc;3978497.html (dostęp: 23.09.2020).

${ }^{31} \mathrm{H}$. Walczak, P. Witkowski, Instrumenty prawne gwarantujace sprawiedliwość i zaufanie do władz publicznych w prawie administracyjnym - zagadnienia wybrane, [w:] Sprawiedliwość i zaufanie do władz publicznych w prawie administracyjnym, red. M. Kasiński, M. Stahl, K. Wlaźlak, Warszawa 2015, https://sip.lex.pl/\#/monograph/369366334/23/kasinski-michal-redstahl-malgorzata-red-wlazlak-katarzyna-red-sprawiedliwosc-i-zaufanie-do-wladz...?keyword= sprawiedliwo\%C5\%9B\%C4\%87\&cm=SREST (dostęp: 23.09.2020).

32 A. Łazarska, Rzetelny a sprawiedliwy proces - dyferencjacja wartości [w:] Rzetelny proces cywilny, Warszawa 2012, https://sip.lex.pl/\#/monograph/369253790/21/lazarska-aneta-rzetelnyproces-cywilny?keyword $=\% 22$ poj $\% \mathrm{C} 4 \% 99 \mathrm{cie} \% 20$ sprawiedliwo $\% \mathrm{C} 5 \% 9 \mathrm{Bci} \% 22 \&$ unitId $=$ passage_2231 (dostęp: 28.10.2020).

33 W. Jakimowicz, op. cit.

34 S. Nitecki, Prawo do pomocy społecznej w polskim systemie prawnym, Warszawa 2008, https://sip.lex.pl/\#/monograph/369182600/27/nitecki-stanislaw-prawo-do-pomocy-spolecznej-wpolskim-systemie-prawnym?keyword=\%22poj $\% \mathrm{C} 4 \% 99 \mathrm{cie} \% 20$ sprawiedliwo $\% \mathrm{C} 5 \% 9 \mathrm{Bci} \% 22 \& \mathrm{u}-$ nitId=passage_4197 (dostęp: 28.10.2020). 
P. Nowik pisze o pojęciu sprawiedliwości w znaczeniu deontycznym. Jego zdaniem sprowadza się do tak zwanej sprawiedliwości społecznej, którą rozumie jako konieczną $\mathrm{w}$ zastosowaniu, ,jeśli mamy unikać rozstrzygnięć rażąco niesłusznych". Autor ten rozpatruje to pojęcie z punktu widzenia zasad konstytucyjnych, twierdząc, iż w istocie sprawiedliwości „dostrzegamy pewną dyspozycję skierowaną do podmiotów (uczestników) procesu równoważenia praw, która ogranicza skrajną możliwość zróżnicowania członków społeczeństwa"35.

Warto przy tym zwrócić uwagę na związek pojęcia "sprawiedliwości” z zagadnieniem świadczeń socjalnych i redystrybucji dóbr. Już Arystoteles uczył o sprawiedliwości wyrównawczej i sprawiedliwości rozdzielczej. Pierwszą z nich rozumiał w sposób uproszczony jako „stosowne” i „w proporcji” odpłacanie dobrem za dobro bądź złem za zło. Drugą natomiast jako identyczne traktowanie osób o takich samych cechach (warunkach istnienia, zasługach) uznanych za kluczowe dla rozdzielania jakiegoś dobra bądź nakładania obowiązku. Sprawiedliwość dystrybutywną wiązał niekiedy z przesłanką „,według zasług”, polegającą na określonym aktywnym zachowaniu, na przykład wzmożonej pracy.

W moim przekonaniu na zaakcentowanie zasługuje pogląd S. Niteckiego, którego zdaniem w sprawach świadczeń to właśnie pojęcie sprawiedliwości odgrywa kluczową rolę. Pisze on, iż: „W pierwszej kolejności należy zwrócić uwagę na to, że pomoc społeczna i świadczenia przyznawane w jej ramach regulowane są przepisami prawa powszechnie obowiązującego, a zatem występuje tu powiązanie sprawiedliwości z prawem, które będzie się sprowadzało do tego, że wszelkie świadczenia pomocy społecznej przyznawane osobom i rodzinom pozostającym w trudnej sytuacji życiowej regulowane są przez prawo. Tym samym sprawiedliwe będzie przyznanie świadczenia osobie czy rodzinie spełniającej wymogi określone w przepisach regulujących zasady ich przyznawania" ${ }^{36}$.

\section{ORZECZNICTWO SĄDOWOADMINISTRACYJNE „PO SPRAWIEDLIWOŚCI”}

W wyrokach Sądu Najwyższego spotyka się pogląd — z którym nie sposób się w pełni nie zgodzić — że na powszechnie akceptowalną (zarówno w orzecznictwie, jak i piśmiennictwie) zasługuje zasada pierwszeństwa wykładni językowej, a następnie subsydiarności, interpretacji systemowej oraz funkcjonalnej. Zdaniem SN co prawda zasada pierwszeństwa wykładni językowej (choć zasadniczej) nie ma charakteru absolutnego, jednakże dopuszcza się odstępstwa od niej jedynie

35 P. Nowik, Oddziaływanie negocjacji zbiorowych na ustawę w prawie pracy, [w:] Zakładowy dialog spoleczny, red. J. Stelina, Warszawa 2014.

36 S. Nitecki, op. cit. 
wtedy, gdy „wynik jej zastosowania prowadzi albo do absurdu, albo do konsekwencji rażąco niesprawiedliwych lub irracjonalnych"37.

W moim przekonaniu widać jednak, że w orzecznictwie sądów administracyjnych w przedmiocie świadczeń rodzinnych mamy do czynienia $\mathrm{z}$ odstępowaniem od wykładni językowej nie tylko w okolicznościach, gdy semantyczne rozumienie przepisu jest absurdalne, nieracjonalne bądź rażąco niesprawiedliwe.

Przykłady odstępstw od wykładni językowej widoczne są w sprawach administracyjnych dotyczących przyznawania świadczenia pielęgnacyjnego. Zgodnie $\mathrm{z}$ art. 17 ust. $1 \mathrm{~b}$ ustawy o świadczeniach rodzinnych ${ }^{38}$ świadczenie pielęgnacyjne przysługuje, jeżeli niepełnosprawność osoby wymagającej opieki powstała: 1. nie później niż do ukończenia 18 roku życia lub 2. w trakcie nauki w szkole lub w szkole wyższej, jednak nie później niż do ukończenia 25 roku życia. Przepis ten, choć swego czasu jako różnicujący osoby ze względu na wiek powstania niepełnosprawności został uznany za niekonstytucyjny, cały czas obowiązuje w niezmienionej treści.

W zdecydowanej większości sądy administracyjne jednakże stwierdziły, iż (jak przykładowo WSA w Szczecinie) „nie sposób zgodzić się ze stanowiskiem, że skoro wyrok Trybunału Konstytucyjnego nie uchylił mocy obowiązującej art. 17 ust. $1 \mathrm{~b}$ u.ś.r. i nie stanowi on podstawy do uchylenia decyzji przyznających prawo do świadczenia pielęgnacyjnego, jak i nie kreuje nowego prawa do żądania świadczenia przez opiekunów dorosłych osób niepełnosprawnych jeżeli niepełnosprawność ich podopiecznych nie powstała w okresie dzieciństwa, a ustawodawca nie dokonał dotąd zmiany omawianego przepisu to mimo, iż jest on niezgodny z Konstytucją RP, nadal obowiązuje w stanie prawnym i ma dla organów charakter bezwzględnie obowiązujący"39. Identycznie orzekał WSA w Krakowie. Pouczał on organy administracji, że rozpoznając wniosek o przyznanie świadczenia pielęgnacyjnego złożony przez opiekuna dorosłej osoby niepełnosprawnej, organy mają obowiązek zbadać, czy wnioskodawca spełnia warunki do przyznania tego świadczenia określone w art. 17 u.ś.r., z wyłączeniem tej części tego przepisu, która została ostatecznie uznana za niekonstytucyjną ${ }^{40}$. Sądy — jak się zdaje — przyjęły jako swoje wyjaśnienia Trybunału Konstytucyjnego, iż odmienne traktowanie tych osób, które sprawują opiekę nad niepełnosprawnymi w różnym wieku, jest niezgodne z zasadą równości i nie znajduje uznania w świetle zasady sprawiedliwości społecznej ${ }^{41}$. Tym samym — choć jak pouczał TK, wyrok nie oznacza usunięcia

37 Wyrok SN z dnia 19 maja 2015 roku, III CZP 114/14, LEX nr 1681981; por. między innymi także wyrok SN z 11 kwietnia 2008 roku, II CSK 650/07, LEX nr 391825.

38 Ustawa z dnia 28 listopada 2003 roku o świadczeniach rodzinnych (Dz.U. z 2020 r. poz. 111 ze zm.; dalej: u.ś.r.).

39 Wyrok WSA w Szczecinie z dnia 14 września 2017 roku, II SA/Sz 761/17.

40 Wyrok WSA w Krakowie z dnia 26 lipca 2017 roku, III SA/Kr 647/17.

41 Komunikat po wyroku TK K 38/13, https://trybunal.gov.pl/postepowanie-i-orzeczenia/ komunikaty-prasowe/komunikaty-po/art/7169-prawo-do-swiadczenia-pielegnacyjnego (dostęp: 4.01.2021). 
kryterium wieku powstania niepełnosprawności, jak też nie kreuje nowego prawa do żądania świadczenia przez opiekunów osób niepełnosprawnych, jeżeli ich niepełnosprawność powstała już po okresie dzieciństwa ${ }^{42}$ — sądy administracyjne stoją $\mathrm{w}$ przeświadczeniu, że wiek powstania niepełnosprawności nie może mieć w kwestii przyznania świadczenia doniosłości prawnej, ponieważ jest niezgodny z zasadą sprawiedliwości i równości.

Podobnie w sprawach dotyczących świadczeń pielęgnacyjnych — wykładnia literalna zastąpiona została interpretacją ,prosprawiedliwościową" w odniesieniu do problematyki przyznawania świadczenia osobom, które mają ustalone prawo do emerytury bądź renty.

$Z$ literalnej treści art. 17 ust. 5 pkt 1 lit. a u.ś.r. wywodzimy, że świadczenie pielęgnacyjne nie przysługuje, jeżeli osoba sprawująca opiekę ma ustalone prawo do emerytury (renty, renty rodzinnej, renty socjalnej, zasiłku stałego, nauczycielskiego świadczenia kompensacyjnego, zasiłku przedemerytalnego, świadczenia przedemerytalnego lub rodzicielskiego świadczenia uzupełniającego).

Przepis ten jawi się jako konkretny i oczywisty — jeśli osoba ma ustalone określone prawo (emerytura, renta itp.), to nie przysługuje jej przedmiotowe świadczenie. Sądy administracyjne doszły jednak do wniosku, że literalna wykładnia przepisu narusza fundamenty aksjologiczne wyrażone w Konstytucji RP o tyle, o ile pozbawia prawa do świadczenia pielęgnacyjnego osoby mające uprzednio ustalone prawo do emerytury (renty) w wysokości niższej niż to świadczenie.

NSA, powołując się na szereg wyroków $\mathrm{TK}^{43}$, stwierdził, że istotne z punktu widzenia sprawy są zasady równości wobec prawa (art. 32 ust.1 Konstytucji), sprawiedliwości społecznej (art. 2 Konstytucji), obowiązku udzielania szczególnej pomocy rodzinom znajdującym się w trudnej sytuacji materialnej i społecznej (art. 71 ust. 1 zdanie drugie Konstytucji) i osobom niepełnosprawnym (art. 69 Konstytucji), dlatego też

wszystkie podmioty prawa (adresaci norm prawnych), charakteryzujące się daną cechą istotną (relewantną) w równym stopniu, mają być traktowane równo, a więc według jednakowej miary, bez różnicowań zarówno dyskryminujących, jak i faworyzujących. Jeżeli zatem prawodawca różnicuje podmioty prawa, które charakteryzują się wspólną cechą istotną, to wprowadza odstępstwo od zasady równości ${ }^{44}$.

Za przykładem NSA poszły również wojewódzkie sądy administracyjne. Przykładowo WSA w Gdańsku uzasadnił odmienną od literalnej wykładnię art. 17 ust. 5 pkt 1 lit. a u.ś.r. wyrażoną w art. 8 ust. 2 Konstytucji RP zasadą bezpośred-

42 Ibidem.

43 Wyrok TK z dnia 9 marca 1988 roku, U 7/87, a także wyroki TK z: 6 maja 1998 roku, 37/97; 20 października 1998 roku, K 7/98; 17 maja 1999 roku, P 6/98; 4 stycznia 2000 roku, K 18/99; 18 grudnia 2000 roku, K 10/00; 21 maja 2002 roku, K 30/01; 28 maja 2002 roku, P 10/01; 18 marca 2014 roku, SK 53/12.

44 Wyroki NSA z dnia 8 stycznia 2020 roku, I OSK 2392/19; z dnia 30 kwietnia 2020 roku, I OSK 1546/19. 
niego stosowania jej przepisów i obowiązkiem organów władzy publicznej dokonywania prokonstytucyjnej wykładni ,pozwalającej na realizację zasad: równości wobec prawa (art. 32 ust. 1) i sprawiedliwości społecznej (art. 2)"45.

Poprzez sądową „racjonalizację” odejścia od semantyki wspomnianego przepisu doszło do powszechnej akceptacji dla uzyskiwania świadczenia pielęgnacyjnego w okoliczności posiadania prawa do emerytury bądź renty. Między innymi WSA w Rzeszowie zaakcentował, że

ustawodawcy konstruującemu negatywną przesłankę przyznania świadczenia pielęgnacyjnego w postaci emerytury, chodziło o wykluczenie sytuacji pobierania przez opiekuna w tym samym czasie dwóch świadczeń z systemu zabezpieczenia społecznego o tym samym przeznaczeniu, czyli mających dostarczać uprawnionemu środków utrzymania. Decyzja o zawieszeniu emerytury, która będzie skutkować wstrzymaniem wypłaty związanych z tym środków, skutecznie eliminuje zagrożenie kumulowania świadczeń i tym samym nadużywania prawa do zabezpieczenia społecznego ${ }^{46}$.

W ten sposób umożliwiono ubieganie się o świadczenie pielęgnacyjne osobom, które pobierały dotychczas rentę, emeryturę lub inne wymienione w wyżej cytowanych przepisie.

Sądową wykładnię „po sprawiedliwości” widać również w sprawach dotyczących przyznania świadczeń pielęgnacyjnych osobom pozostającym w związku małżeńskim z niepełnosprawnym.

Regulujący tę kwestię art. 17 ust. 5 pkt 2 lit. a u.ś.r. stanowi, iż świadczenie pielęgnacyjne nie przysługuje, jeżeli osoba wymagająca opieki pozostaje w związku małżeńskim, chyba że współmałżonek legitymuje się orzeczeniem o znacznym stopniu niepełnosprawności. Wykładnia literalna prowadzi do jednoznacznego wniosku, że o ile małżonek osoby wymagającej opieki sam tej opieki nie wymaga (to jest nie legitymuje się orzeczeniem o znacznej niepełnosprawności), to świadczenie pielęgnacyjne takiemu małżonkowi (opiekującemu się niepełnosprawnym współmałżonkiem) nie przysługuje.

Z orzecznictwa sądowego wyprowadzić można tezę zupełnie odmienną. Jak wskazywał WSA w Łodzi, ,pominięcie współmałżonka wśród osób uprawnionych do świadczenia pielęgnacyjnego uznawane jest wręcz za rozwiązanie dyskryminujące i pozostające w sprzeczności z podstawowym ratio tegoż świadczenia”. Zdaniem tego sądu, „celem ustawy o świadczeniach rodzinnych jest realizacja polityki społecznej i gospodarczej uwzględniającej dobro rodzin znajdujących się w trudnej sytuacji” i dlatego ,wyłączenie małżonka z kręgu uprawnionych do wsparcia, a tym samym uznanie, że obowiązek współmałżonków do wzajemnego dostarczania środków utrzymania nie jest obowiązkiem alimentacyjnym [...] pozostaje w sprzeczności z aksjologiczną racjonalnością ustawodawcy’"47.

45 Wyrok WSA w Gdańsku z dnia 12 grudnia 2020 roku, III SA/Gd 759/20.

46 Wyrok WSA w Rzeszowie z dnia 8 września 2020 roku, II SA/Rz 447/20.

47 Wyrok WSA w Łodzi z dnia 29 maja 2012 roku, II SA/Ld 370/12; por. wyroki: WSA w Olsztynie z dnia 18 sierpnia 2011 roku, III SA/Ol 456/11; WSA w Rzeszowie z dnia 8 marca 2011 
Sądy przyjęły zatem, że choć wyraźnie semantyka cytowanego przepisu wyłącza zdrowego małżonka osoby niepełnosprawnej z grona osób, które mogą ubiegać się o świadczenie pielęgnacyjne, to jest to dyskryminacyjne i niesprawiedliwe.

Przykłady „prosprawiedliwościowego” orzecznictwa odnajdujemy też w sprawach dotyczących warunków nabywania prawa do świadczeń rodzinnych przez osoby faktycznie opiekujące się dzieckiem.

Zgodnie z treścią art. 2 pkt 1 uś.r. do świadczeń rodzinnych zaliczamy między innymi zasiłek rodzinny oraz dodatki do zasiłku rodzinnego. Świadczenie to służy zaspokojeniu podstawowych potrzeb dziecka oraz dbałości o jego dobro, ale skierowane jest do podmiotów, które sprawują opiekę (art. 4 ust. 2 u.ś.r), to jest rodzicom, jednemu z rodziców albo opiekunowi prawnemu dziecka, opiekunowi faktycznemu dziecka.

Opiekun faktyczny dziecka, zgodnie z definicją określoną w art. 3 pkt 14 u.ś.r. to zaś osoba faktycznie opiekująca się dzieckiem, jeżeli wystąpiła z wnioskiem do sądu rodzinnego o przysposobienie. Tym samym wśród osób uprawnionych do ubiegania się o świadczenia rodzinne prawodawca nie uwzględnił osób, które choć nie wystąpiły z wnioskiem o przysposobienie - sprawują faktycznie bieżącą pieczę nad dzieckiem z mocy orzeczenia sądu.

W opinii sądów administracyjnych należy jednak uznać, że (jak choćby pouczają NSA i WSA w Łodzi), ,przepisy tej ustawy w sposób niedostateczny chronią prawa jednostki, jaką jest rzeczywisty opiekun dziecka, sprawujący nad nim bieżącą pieczę”, jak też „nie chronią praw dzieci, na rzecz których świadczenie jest przewidziane”. Tym samym ,fakt iż ustawa posługuje się autonomiczną definicją, a sama wykładnia językowa pozwala na ustalenie jej treści, nie wyłącza potrzeby i konieczności zastosowania innych zasad wykładni w sytuacji, gdy wynik wykładni językowej jest sprzeczny z podstawowymi zasadami konstytucyjnymi"48.

Podobnie stwierdził WSA w Gliwicach, konstatując, iż „ograniczenia w dostępności do zasiłku rodzinnego na podstawie ustawy o świadczeniach rodzinnych dla osoby sprawującej pieczę bieżącą nad dzieckiem na mocy prawomocnego orzeczenia sądu rodzinnego godzą [...] w interes osoby dziecka, chroniony ustawą zasadniczą i umową międzynarodową, co pozwala na wywiedzenie owego uprawnienia wprost z postanowień Konstytucji Rzeczpospolitej Polskiej i Konwencji o Prawach Dziecka"49.

Widać zatem, że sądy przyjęły, iż w sprawach tego rodzaju wykładnia językowa nie ma priorytetu nad innymi dyrektywami interpretacyjnymi.

roku, II SA/Rz 40/11; WSA w Gliwicach z dnia 11 października 2011 roku, IV SA/Gl 467/10; WSA w Gliwicach z dnia 9 listopada 2010 roku, IV SA/Gl 276/10; WSA w Warszawie z dnia 9 czerwca 2010 roku, I SA/Wa 604/10; WSA w Warszawie z dnia 21 października 2009 roku, VIII SA/Wa $373 / 09$.

48 Wyrok NSA z dnia 1 sierpnia 2019 roku, I OSK 202/19; por. wyrok WSA w Łodzi z dnia 22 listopada 2019 roku, II SA/Łd 239/19.

49 Wyrok WSA w Gliwicach z dnia 4 kwietnia 2014 roku, IV SA/Gl 695/13. 
Warto również zwrócić uwagę na opinie judykatury w zakresie definiowania zwrotu „osoba samotnie wychowująca dziecko” na potrzeby spraw dotyczących przyznawania dodatku z tytułu samotnego wychowywania dziecka. Jedna z linii orzeczniczych sądów administracyjnych pozwala bowiem na przyjęcie, iż taką osobą jest również rodzic, który wychowuje swoje dziecko będąc w związku małżeńskim.

Treść art. 3 pkt 17a u.ś.r. zdaje się oczywista. Ustawodawca wskazał, że osoba samotnie wychowująca dziecko to panna, kawaler, wdowa, wdowiec, osoba pozostająca w separacji orzeczonej prawomocnym wyrokiem sądu, osoba rozwiedziona, chyba że wychowuje wspólnie co najmniej jedno dziecko z jego rodzicem.

W wyrokach sądów administracyjnych legalna definicja osoby samotnie wychowującej dziecko, poza wskazaniem stanu cywilnego takiej osoby, kładzie jednak nacisk na fakt wychowywania dziecka bez równoczesnego uczestnictwa w tym procesie jednego z jego rodziców, odpowiednio matki lub ojca tego dziecka. Jak pouczał WSA we Wrocławiu, ,aby danej osobie można było przypisać status osoby samotnie wychowującej dziecko [...] musi ona samotnie to jest bez udziału drugiego rodzica wychowywać dziecko" 50 .

Co jednak — w moim przekonaniu — budzi kontrowersje, sądy często przyjmują że „fakt zawarcia nowego związku małżeńskiego przez rodzica samotnie wychowującego dziecko nie ma wpływu na sferę władzy rodzicielskiej” i dlatego też „uznać należy, że dziecko wychowujące się w rodzinie rekonstruowanej nie traci statusu osoby wychowywanej przez samotnego rodzica"51.

\section{PODSUMOWANIE}

Wybrane przykłady orzeczeń sądów administracyjnych pozwalają na potwierdzenie tezy, iż judykatura, w sprawach dotyczących świadczeń rodzinnych, stoi na straży sprawiedliwości (w tym konstytucyjnej zasady sprawiedliwości społecznej) nawet wtedy, gdy jest to wprost sprzeczne z literalnym zamiarem prawodawcy. W praktyce nie budzi wątpliwości, iż ograniczone środki budżetowe przeznaczane na świadczenia socjalne (rodzinne) prowadzą do takich działań legislacyjnych, które mają bardziej ograniczać, niż powiększać, krąg osób uprawionych do pomocy. Ta okoliczność jest jakby zupełnie (być może słusznie) w orzecznictwie sądowym pomijana, zaś wyroki w których sądy „wykładając” przepisy, uznają je za niesprawiedliwe i dokonują interpretacji w sposób sprzeczny z ich literalnym brzmieniem, są na tyle powszechne, iż tworzą ugruntowane linie orzecznicze.

50 Wyrok WSA we Wrocławiu z dnia 4 kwietnia 2016 roku, IV SA/Wr 503/15.

51 Wyrok WSA w Gdańsku z dnia 2 kwietnia 2014 roku, III SA/Gd 108/14. 


\title{
LAW VS. JUSTICE IN THE PROCESS OF JUDICIAL INTERPRETATION OF THE NORMS OF THE RIGHT TO FAMILY BENEFITS
}

\begin{abstract}
Summary
The article aims to draw attention to the problem of 'omitting' the literal content of the law by administrative courts and focusing on the idea of justice and equality. This problem is particularly visible in relation to the issue of social benefits. It can lead to a disturbance of the sense of law uniformity and clarity among citizens.
\end{abstract}

Keywords: family benefits, legal interpretation, administrative judgements, justice, public administration

\section{BIBLIOGRAFIA}

Bielska-Brodziak A., Interpretacja tekstu prawnego na podstawie orzecznictwa podatkowego, Warszawa 2009.

Brzeziński B., Podstawy wykładni prawa podatkowego, Gdańsk 2008.

Cieślak M., Polska procedura karna. Podstawowe założenia teoretyczne, Warszawa 1984.

Grzybowski T., Wptyw zmian prawa na jego wyktadnię, Warszawa 2013.

Jakimowicz W., Wyktadnia w prawie administracyjnym, Kraków 2006.

Jędrejek G., Wyktadnia przepisów prawa cywilnego materialnego i procesowego, Warszawa 2020. Łazarska A., Rzetelny proces cywilny, Warszawa 2012.

Kołakowski L., Po co nam pojęcie sprawiedliwości społecznej?, „Gazeta Wyborcza” 1995, nr 105. Morawski L., Zasady wyktadni prawa, Torun 2010.

Nitecki S., Prawo do pomocy społecznej w polskim systemie prawnym, Warszawa 2008.

Nowik P., Oddziaływanie negocjacji zbiorowych na ustawę w prawie pracy, [w:] Zakładowy dialog społeczny, red. J. Stelina, Warszawa 2014.

Radwański Z., Zastosowanie wykładni językowej w prawie Unii Europejskiej, [w:] Aurea praxis. Aurea theoria. Księga pamiątkowa ku czci Profesora Tadeusza Erecińskiego. t. 2, red. J. Gudowski, K. Weitz, Warszawa 2011.

Rogoziński P., Glosa do uchwały Sądu Najwyższego z dnia 29 października 2012 r., sygn. I KZP 15/12, „Prokuratura i Prawo” 2014, nr 1.

Smoktunowicz E., Orzecznictwo Sądu Najwyższego i Naczelnego Sądu Administracyjnego: kodeks postępowania administracyjnego, Warszawa 1994.

Walczak H., Witkowski P., Instrumenty prawne gwarantujace sprawiedliwość i zaufanie do władz publicznych w prawie administracyjnym - zagadnienia wybrane, [w:] Sprawiedliwość i zaufanie do władz publicznych w prawie administracyjnym, red. M. Kasiński, M. Stahl, K. Wlaźlak, Warszawa 2015.

Waśkowski E., Teorja wykladni prawa cywilnego. Metodologja dogmatyki cywilistycznej w zarysie, Warszawa 1936.

Wyktadnia w prawie administracyjnym, red. L. Leszczyński, B. Wojciechowski, M. Zirk-Sadowski, Warszawa 2012.

Zieliński M., Wybrane zagadnienia wyktadni prawa, „Państwo i Prawo” 2009, z. 6.

Zirk-Sadowski A., Pojęcie, koncepcje i przebieg wykładni prawa administracyjnego, [w:] System prawa administracyjnego, red. R. Hauser, Z. Niewiadomski, A. Wróbel, t. 4, Warszawa 2015. 